УДК 539.2:533.9(07)

\title{
Nanodispersed Mg-based Powders Received in a Hydrogen-argon Plasma Flow and Estimation of their Application Prospects as Hydrogen Storage Materials
}

\author{
Evgenia I. Melnikova \\ Institute of Engineering Physics and Radio Electronics \\ Siberian Federal University \\ Svobodny, 79, Krasnoyarsk, 660041 \\ Russia \\ Andrey L. Kolonenko \\ Gari A. Glushenko \\ Natalya G. Vnukova \\ Grigory N. Churilov* \\ Kirensky Institute of Physics SB RAS \\ Akademgorodok, 50/38, Krasnoyarsk, 660036 \\ Russia \\ Anatoly M. Zhizhaev \\ Institute of Chemistry and Chemical Technology \\ Akademgorodok 50/24, Krasnoyarsk, 660036 \\ Russia
}

Received 12.03.2016, received in revised form 02.09.2016, accepted 20.11.2016

Nanodispersed powders, consisting of $\mathrm{Mg}, \mathrm{Mg}$ and $\mathrm{Ni}, \mathrm{Mg}$ and $\mathrm{Pd}$, were synthesized in a water-cooled chamber in a hydrogen-helium mixture at atmospheric pressure. Plasma generation was carried out in $H F$ arc discharge in an argon flow with one hollow electrode and the other - crucible with molten metal. The resulting powders were investigated by scanning electron microscopy, X-ray fluorescence analysis and X-ray analysis. When adding nickel during the synthesis, magnesium particles with nickel coating were obtained. Synthesis with palladium resulted in producing magnesium particles with dispersed fine palladium inclusions. However, since the saturated steam pressure of palladium is 2-3 orders lower than that of nickel, then obtaining particles coated with palladium is only possible at higher palladium melt temperatures that we could achieve in this laboratory setup variant. As a possible application of the synthesized powders the possibility of their hydrogen storage usage was experimentally evaluated.

Keywords: magnesium powder, plasma-chemical synthesis, hydrogen storage.

DOI: $10.17516 / 1997-1397-2017-10-1-75-82$.

\section{Introduction}

It is widely known, that the composition and properties of the nanoscaled powders depend strongly on their synthesis method. The ways of producing metal nanoscaled powders can be

\footnotetext{
*churilov@iph.krasn.ru

(c) Siberian Federal University. All rights reserved
} 
divided into two main groups. In the first, nanoparticles are formed by dispersing the bulk materials "top-down", in the second - by coagulation from vapor or plasma state — "bottomup".

The first group includes such methods as mechanical grinding, detonation synthesis, severe plastic deformation (equal-channel angular pressing) and others. They are characterized by the possibility of producing the end-product in a great number, but the time costs for producing are significantly high. "Bottom-up" synthesis can be implemented in various vapor deposition ways, which are characterized by the powder contamination absence of abradable materials and relatively little synthesis time. Plasma-chemical methods of producing micro- and nanoscaled powders, based on the usage of electric, high-frequency and induction plasma discharges, are considered as the most highly productive. The disadvantage of the induction plasma discharge, compared with arc discharge, is its low energy saturation associated with the electron temperature separation from the gas temperature and low efficiency of energy transfer from generator to plasma. The disadvantage of the electric plasma generation method is the pollution of obtained powders by electrode erosion products [1]. The using of a high frequency current for plasma generating in a discharge with a hollow water-cooled electrode can prevent this drawback [2].

Metal particles in nanodispersed state, in contrast to the bulk metal particles, are capable of exhibiting different hydrogen sorption characteristics due to increasing the surface atoms proportion and electronic states changes with size decreasing. But at the same time, metal nanoparticles have sufficiently high chemical activity and are prone to oxidation and aggregation. Therefore, to reduce unacceptable impurities pollution and to increase the hydrogen dissociation rate near the surface, metal particles are coated with a protective shell of transition metal, oxides, [3,4] or carbon [5].

In this paper magnesuim used as a core since it can form a stable hydride with a hydrogen capacity of 7,6 wt.\%, thereby it is considered as a very promising candidate for onboard applications [6]. Literature data [7-10] suggest that the hydrogen diffusion rate increases when adding certain metals into the nanodispersed magnesium powders and the onset temperature of hydrogen desorption reduces. To obtain nanodispersed magnesium powders plasma generation was carried out in a unique, well-studied earlier HF arc discharge in an argon flow with one hollow electrode and the other - crucible with molten metal ( $\mathrm{Mg}$ or $\mathrm{Mg}$ and $\mathrm{Ni}$ and $\mathrm{Pd}$ ). The camera was supplied with helium for improvement of gaseous medium thermal conductivity, and hydrogen for undesirable oxygen impurities bonding.

\section{Experimental details}

Fig. 1 shows our plasma-chemical setup used for nanoparticles synthesis.

Plasma generation was carried out in a water-cooled sealed chamber (1) by a principle and scheme described by Churilov et al. [11]. In the chamber there were located two electrodes: the water-cooled hollow nickel rod (2) and magnesium (3). Magnesium was placed into the crucible consisting of a quartz tube (4) and a graphite base (5) and was heated by the inductor (6) to a temperature of $600-700^{\circ} \mathrm{C}$. The $\mathrm{AC}$ arc discharge $(66 \mathrm{KHz}, 12 \mathrm{~A})$ (7) was carried out between the nickel electrode and the molten magnesium. Argon (plasma forming gas) was inflated through an axial bore of the nickel rod. The hydrogen supply was carried out through the space between a nickel rod and a water-cooled pipe (8), helium supply - through a lateral hole of the chamber. Gas was inflated with the rate: $\mathrm{H}_{2}-5 \mathrm{l} / \mathrm{min}, \mathrm{Ar}-5 \mathrm{l} / \mathrm{min}, \mathrm{He}-3 \mathrm{l} / \mathrm{min}$. The presence of hydrogen allowed to reduce the oxygen impurities content in the chamber and thus shorten the 


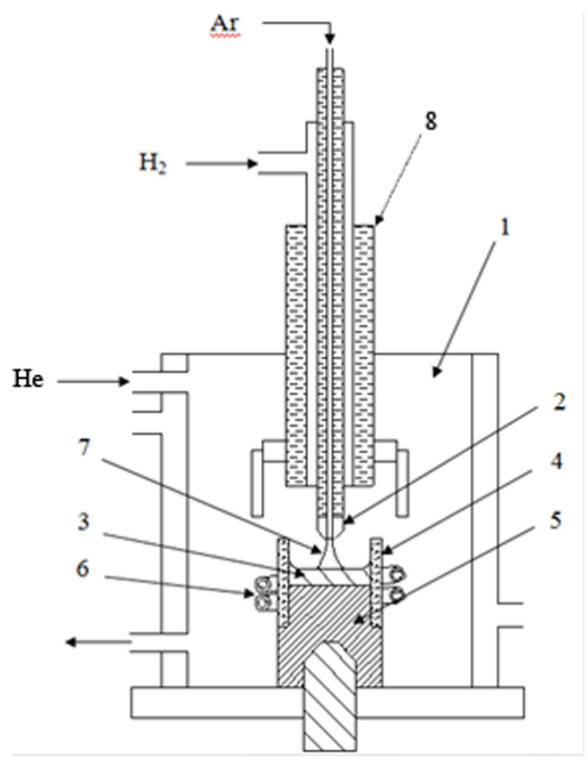

Fig. 1. Plasma-chemical setup for the nanoparticles synthesis: 1 - water-cooled sealed chamber; 2 - water-cooled hollow nickel rod; 3 - molten magnesium; 4 - quartz tube; 5 - graphite crucible; 6 - inductor; 7 - arc discharge; 8 - water-cooled pipe

oxide film thickness of the synthesized nanoparticles. The same effect could be achieved only by using expensive pure gases.

Besides pure magnesium (sample 1), magnesium with metal additives: $\mathrm{Mg}-\mathrm{Ni}$ (sample 2) and Mg-Pd (sample 3) was used.

\section{Results and discussion}

Using scanning electron microscopy of the high resolution microscope SEM Hitachi S-5500 particles size and morphology were defined (Fig. 2). Apparently from the resulted drawings, the average particles size varied within 50-100 nm, but there were large particles about $400 \mathrm{~nm}$ in size. Spheroidal particles and particles, which had a faceting that corresponded to the hexagonal structure, were observed.

The study of the phase composition of the samples was carried out by X-ray diffraction method using DRON-4 powder diffractometer, $\mathrm{Cu} \mathrm{K} \alpha$ radiation. XRD diagrams of the obtained samples (Fig. 3) predominately showed reflections corresponding to Mg. Also there were reflections corresponding to $\mathrm{MgO}$ and $\mathrm{Mg}_{2} \mathrm{Si}$ phases, presented in negligible quantity. Sample 2, in addition to all the above mentioned phases, contained Ni phase.

Further, the obtained powders were hydrogenated under pressure, and analyzed by X-ray diffraction. Diffraction peaks, which characterize $\mathrm{MgH}_{2}$, were on the XRD diagrams of all the investigated samples.

The study of the samples sorption characteristics was performed according to the method developed by Churilov et al. [12], using technical hydrogen (purity 99,9\%). At first, the samples were purified of adsorbed gases by maintaining in vacuum at a temperature $120^{\circ} \mathrm{C}$. Hydrogen sorption was carried out under pressure of $3 \mathrm{MPa}$ at $400^{\circ} \mathrm{C}$ for 10 minutes. Desorption occurred 


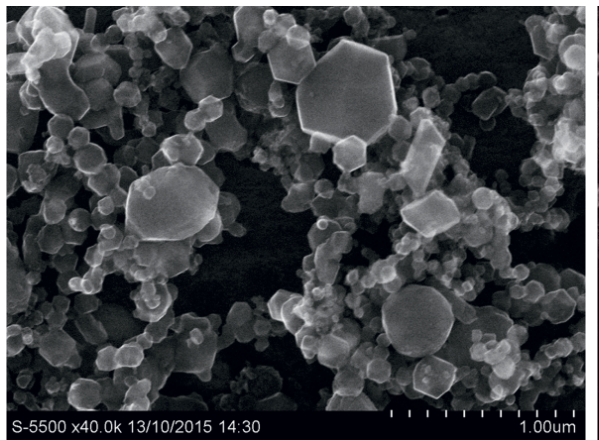

a)

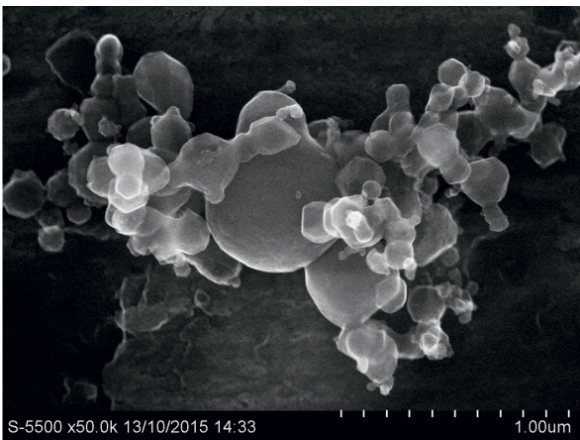

b)

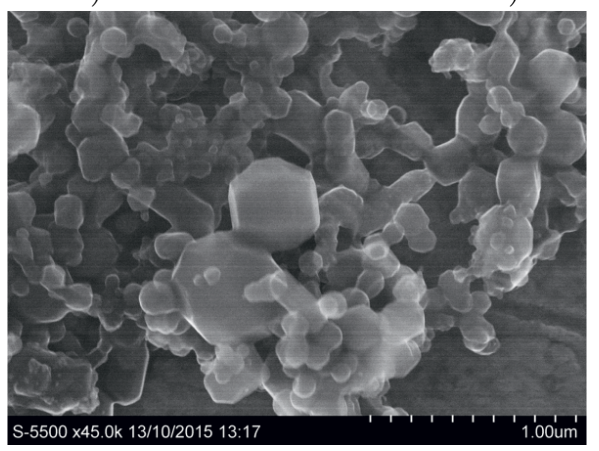

c)

Fig. 2. Electron microscopic images of magnesium nanoparticles: a) sample 1; b) sample 2; c) sample 3

due to sample heating to $600^{\circ} \mathrm{C}$ at $10^{\circ} \mathrm{C} / \mathrm{min}$ rate. Sorption-desorption process was repeated several times for each sample (Fig. 4). The hydrogen evolution took place on average in the temperature range $300-500^{\circ} \mathrm{C}$.

Sample 1 desorbed 3,69 wt.\% and 3,10 wt.\% at the first and third cycles, respectively. Desorption onset temperature was $300^{\circ} \mathrm{C}$. The sorption capacity decline was due to the utilization of not enough pure hydrogen.

Experimental results did not confirm the theoretical assumptions of some authors that nickel would increase the sorption characteristics of magnesium particles [13,14]. Sample 2 desorbed only 0,3 wt. $\%$ of hydrogen during the first cycle and the desorption onset temperature was $180^{\circ} \mathrm{C}$. In principle, this result is expected, since nickel can pass hydrogen only at above $1000^{\circ} \mathrm{C}$ temperatures. Further recycling testing of this sample was inappropriate because of low sorption capacity obtained.

Desorbed hydrogen mass in sample 3 was 3,58 wt.\% and 3,25 wt. $\%$ at the first and second cycles, respectively. Hydrogen desorption began at $300^{\circ} \mathrm{C}$.

It is shown theoretically that palladium atoms can be epitaxially deposited on the magnesium clusters surface. Due to the fact that the first palladium layer on the magnesium surface is more energetically favorable (energy per $\mathrm{Pd}$ atom is $-3,381 \mathrm{eV}$ ) than the second $\mathrm{Pd}$ layer $(-2,141 \mathrm{eV})$, palladium coating on the magnesium nanoparticle should have a good surface adhesion.

Also quantum chemical calculations have shown [13] that when adding nickel to magnesium the most probable is substitution of magnesium atoms for nickel atoms in the subsurface layer, due to low potential barriers of the nickel atom migration on the magnesium surface, from the 


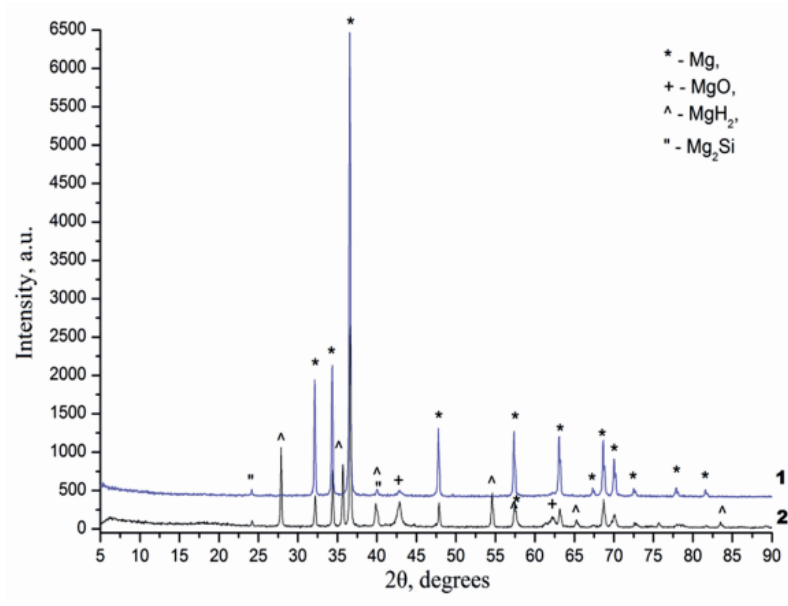

a)

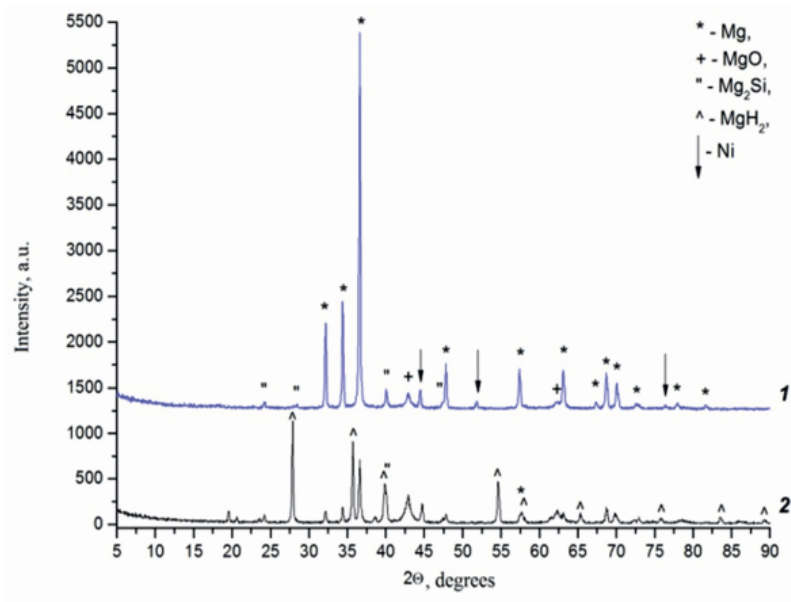

b)

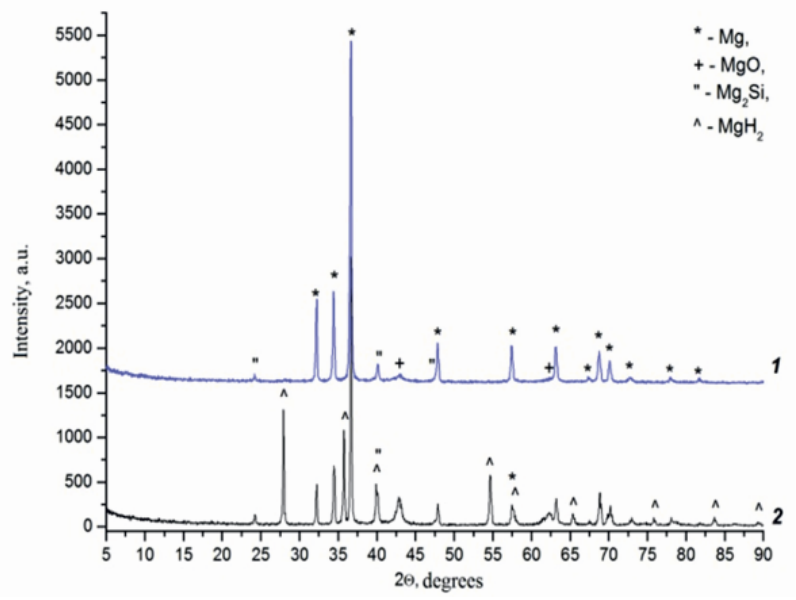

c)

Fig. 3. X-ray diffraction diagrams of the samples before (1) and after hydrogenation under pressure (2): a) sample 1, b) sample 2; c) sample 3

surface into the bulk of the crystal lattice. Nickel cluster deposition on the magnesium surface is hindered, but feasible with proper selection of synthesis parameters, in particular, a special 


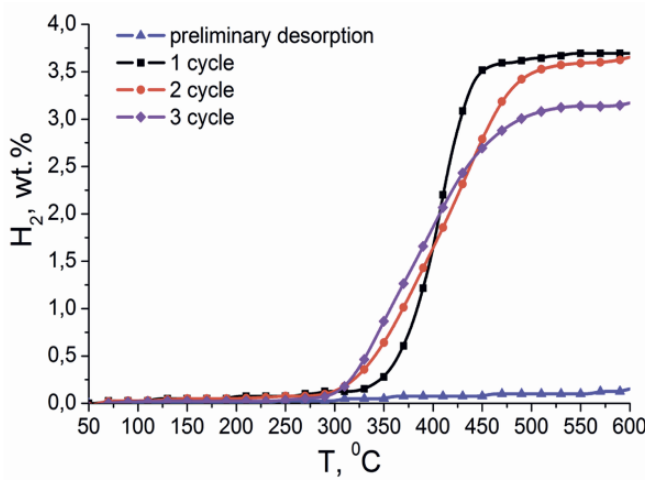

a)

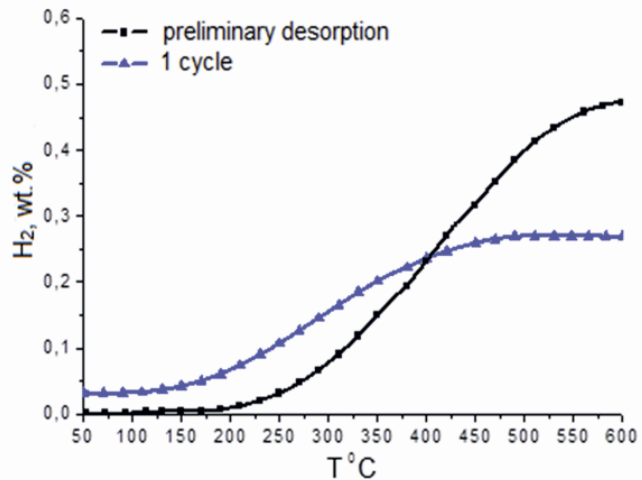

b)

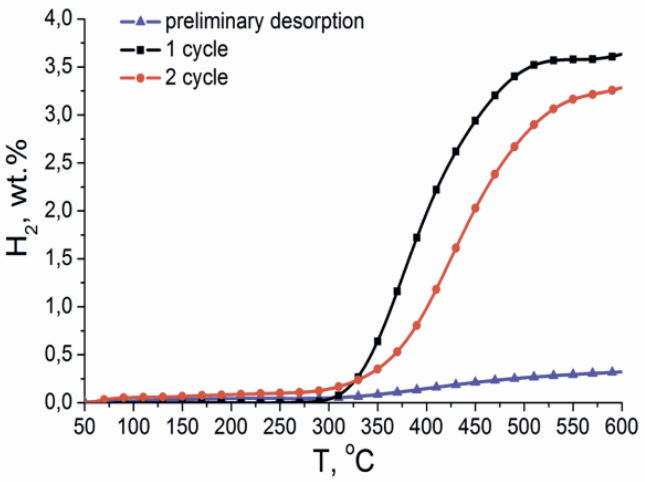

c)

Fig. 4. The desorbed hydrogen mass-temperature dependence curves: a) sample 1; b) sample 2 ; c) sample 3

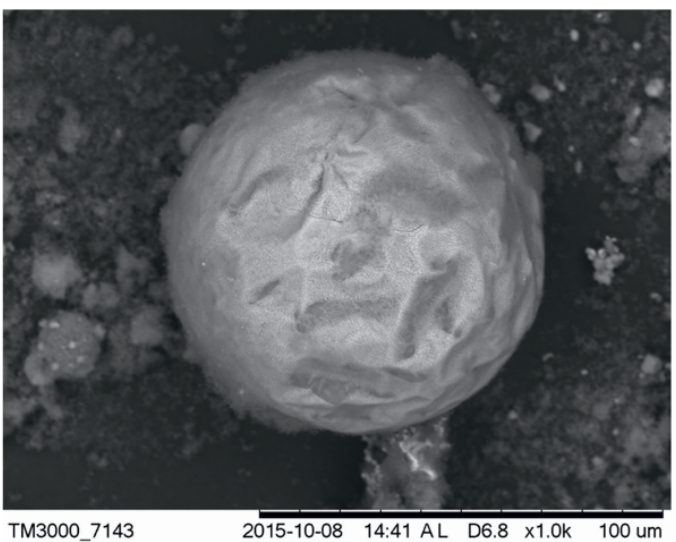

Fig. 5. Scanning electron microscopy of Mg-Ni particles

temperature range at which nickel atoms will diffuse into the bulk of magnesium particles.

Using X-ray microanalysis (Quantax 70 Bruker) it was shown (Fig. 5) that nickel located on the surface of magnesium nanoparticles forming a film, which prevented effective diffusion of hydrogen atoms, but palladium was dispersed over the volume of the sample as separate particles 
that was caused by synthesis parameters. Since the saturated steam pressure of palladium is $2-3$ orders lower than that of nickel, then obtaining particles coated with thin palladium shell is only possible at higher temperatures that were used in this study.

\section{Conclusion}

It is shown that, based on an argon plasma flow containing nickel, magnesium particles with solid or discontinuous nickel coating could be produced. Thus, despite theoretical results, demonstrating an acceleration of the hydrogen diffusion process into magnesium around Ni centers, this effect was not experimentally observed. Protective nickel coating acted as a hydrogen penetration barrier into the magnesium core at not very high temperatures, which are interesting for application. From this perspective, palladium shell is much more promising. However, at metal spraying temperatures attainable in our setup, we were unable to obtain magnesium particles coated with palladium, but theoretical estimates showed that such particles production is possible. Subsequently, in order to protect the magnesium particles surface from the aggressive environment, to reduce the temperature of sorption and desorption and to enhance sorption capacity, it is planned to obtain magnesium nanoparticles with palladium coating and investigate their properties.

The work was supported by Ministry of Education and Science of Russia (Russian-Japanese joined project, Agreement no. 14.613.21.0010, ID RFMEFI61314X0010).

\section{References}

[1] A.A.Rempel, Nanotechnologies. Properties and applications of nanostructured materials, Russ. Him. Rev., 76(2007), (5), 435-46 (in Russian).

[2] G.N.Churilov, Source of light for spectral analysis, Patent RU 2326353 C1, 10.06.2008, IPC G01J3/10 (in Russian).

[3] H.Kobayashi, M.Yamauchi, H.Kitagawa, Y.Kubota et al., Hydrogen Absorption in the Core/Shell Interface of Pd/Pt Nanoparticles, J. Am. Chem. Soc., 130(2008), 1818-1819.

[4] E.Callini, L.Pasquini, E.Piscopiello et al., Hydrogen sorption in Pd-decorated $\mathrm{Mg}-\mathrm{MgO}$ core-shell nanoparticles, Appl. Phys. Lett., 94(2009), 221905-221905-3.

[5] D.S.Jacob, I.Genish, L.Klein, A.Gedanken, Carbon-Coated Core Shell Structured Copper and Nickel Nanoparticles Synthesized in an Ionic Liquid, J. Phys. Chem. B, 110(2006), no. $36,17711-17714$.

[6] B.Sakintuna, F. amari-Darkrim, M.Hirscher, Metal hydride materials for solid hydrogen storage: A review, International Journal of Hydrogen Energy, 32(2007), 1121-1140.

[7] M. Pozzo, D. Alfe, Hydrogen dissociation and diffusion on transition metal (= Ti, Zr, V, Fe, $\mathrm{Ru}, \mathrm{Co}, \mathrm{Rh}, \mathrm{Ni}, \mathrm{Pd}, \mathrm{Cu}, \mathrm{Ag}$ )-doped $\mathrm{Mg}(0001)$ surfaces, International Journal of Hydrogen Energy, 34(2009), 1922-1930.

[8] M.Daryania, A.Simchi, M.Sadati et al., Effects of Ti-based catalysts on hydrogen desorption kinetics of nanostructured magnesium hydride, International Journal of Hydrogen Energy, 39(2014), 21007-21014. 
[9] T.Kimura, H.Miyaoka, T.Ichikawa, Y.Kojima, Hydrogen absorption of catalyzed magnesium below room temperature, International Journal of Hydrogen Energy, 38(2013), 1372813733.

[10] M.Lakhala, M.Bhihi , A.Benyoussef et al., The hydrogen ab/desorption kinetic properties of doped magnesium hydrideMgH2systems by first principles calculations and kinetic Monte Carlo simulations, International Journal of Hydrogen Energy, 40(2015), 6137-6144.

[11] N.G.Vnukova, A.L.Kolonenko, G.A.Glushchenko, A.P. Burkova et al., Rapid analysis of monolithic substances by atomic emission spectroscopy, Pis'ma $v$ ZhETF, 36 (2010), no. 10, 933-934 (in Russian).

[12] G.N.Churilov, I.V.Osipova, E.V.Tomashevich et. al., Hydrogenation of the nanopowders that form in a carbon-helium plasma stream during the introduction of $\mathrm{Ni}$ and $\mathrm{Mg}, Z h E T F$, 113(2011), no. 6, 1057-1062 (in Russian).

[13] A.V.Kuklin, A.A.Kuzubov, P.O Krasnov, et. al., Ni-doping effect of $\operatorname{Mg}(0001)$ surface to use it as a hydrogen storage material, Zh. splavov $i$ soedinenii, 609(2014), 93-99 in (in Russian).

[14] E.Callini, L.Pasquini, T.R.Jensen, E.Bonetti, Hydrogen storage properties of $\mathrm{Mg}-\mathrm{Ni}$ nanoparticles, International journal of hydrogen energy, 38(2013), 12207-12212.

\section{Нанодисперсные порошки $\mathrm{Mg}, \mathrm{Mg}-\mathrm{Ni}, \mathrm{Mg}-\mathrm{Pd}$, полученные в потоке водородоаргоновой плазмы и их характеристики}

Евгения И. Мельникова

Институт инженерной физики и радиоэлектроники

Сибирский федеральный университет Свободный, 79, Красноярск, 660041

Россия

Андрей Л.Колоненко, Гари А.Глушенко

Наталья В. Внукова, Григорий Н. Чурилов, Анатолий М. Жижаев Институт физики им. Л.В.Киренского СО РАН Академгородок, 50/38, Красноярск, 660036

Россия

Нанодисперсные порошки, состоящие из $\mathrm{Mg}, \mathrm{Mg}$ и $\mathrm{Ni}, \mathrm{Mg}$ и $\mathrm{Pd}$, были синтезированы в охлаждаемой водой камере, в гелии, смешанном с водородом при атмосферном давлении. Генерация плазмы осуществляласъ в ВЧ-дуговом разряде в потоке аргона с одним полым электродом и другим тиглем с расплавленным металлом. Полученные порошки исследовались методами растровой электронной микроскопии, рентгенофлуоресцентного анализа и рентгенобазового анализа. При одновременном распылении магния и никеля образовывались порошки, состоящие из частии, магния, покрытых никелевой оболочкой. При одновременном распылении магния и палладия порошки состояли из смеси частич, магния и частии, палладия. Однако так как давление насыщенных паров палладия на 2-3 порядка ниже, чем давление насыщенных паров никеля, то получение частии, покрытых оболочкой палладия, возможно только при более высоких температурах расплава палладия, чем мы могли достигнуть в данном варианте нашей лабораторной установки. В качестве возможного применения синтезированных порошков экспериментально была оценена возможность их использования в виде аккумуляторов водорода.

Ключевые слова: порошок магния, плазмохимический синтез, хранение водорода. 